Економічні науки: збірник наукових праць Луцького національного технічного університету. Серія "Регіональна економіка". Випуск 18 (71). Редкол.: відп. ред. д.е.н., професор Л.Л. Ковальська. Луцьк: ІВВ Луцького НТУ, 2021. 278 с.

УДК 658.8

Кощій О.В. д.е.н., професор

Луцький національний технічний університет

\title{
УПРАВЛІННЯ ЛОГІСТИЧНИМИ ВИТРАТАМИ НА ПІДПРИЄМСТВІ
}

В статті розглянуто питання управління логістичними витратами на вітчизняних підприємствах. Доведено, що недоліки в управлінні логістичними витратами на вітчизняних підприємствах призводять до високих загальних витрат та негативно відображаються на ефективності їх функціонування на ринку та конкурентоспроможності. Обгрунтовано необхідність зниження логістичних витрат на вітчизняних підприємствах. Запропоновано основні напрямки у сфері зниження логістичних витрат на вітчизняних підприємствах.

Ключові слова: вітчизняні підприємства, витрати, логістичні витрати, управління логістичними витратами, зниження логістичних витрат, логістичний контролінг.

\section{Koschiy O.}

\section{LOGISTICS COST MANAGEMENT AT THE ENTERPRISE}

The article substantiates the need to reduce the costs of domestic enterprises and considers the search for ways to reduce them. The important role of reducing the logistics costs of enterprises as a prerequisite for improving the efficiency of their operation in the market is substantiated. The significant lag of Ukraine from the highly developed countries of the world (USA, EU countries, etc.) according to the logistics efficiency index calculated by the World Bank is revealed. A number of shortcomings in the management of logistics costs at domestic enterprises have been identified. It is proved that shortcomings in the management of logistics costs at domestic enterprises lead to high overall costs and negatively affect the efficiency of their operation in the market and competitiveness. The need to reduce logistics costs at domestic enterprises is substantiated. The structure of logistics costs in the context of functional areas of logistics is considered and the areas of logistics that need the most effort to reduce logistics costs are identified. The main directions of reducing logistics costs at domestic enterprises in various functional areas of logistics are proposed: supply logistics, production logistics, distribution logistics. The necessity of application of logistic controlling at the domestic enterprises for maintenance of proper management of logistic expenses is proved. It is described that the introduction of logistics controlling at the enterprise allows to optimize its logistics costs, increase profits and increase the profitability of the market.

Keywords: domestic enterprises, costs, logistics costs, logistics costs management, reduction of logistics costs, logistics controlling. 
Економічні науки: збірник наукових праць Луцького національного технічного університету. Серія "Регіональна економіка". Випуск 18 (71). Редкол.: відп. ред. д.е.н., професор Л.Л. Ковальська. Луцьк: ІВВ Луцького НТУ, 2021. 278 с.

Кощий О.В.

\section{УПРАВЛЕНИЕ ЛОГИСТИЧЕСКИМИ РАСХОДАМИ НА ПРЕДПРИЯТИИ}

В статье рассмотрены вопросы управления логистическими затратами на отечественных предприятиях. Доказано, что недостатки в управлении логистическими затратами на отечественных предприятиях приводят к высоким общим расходам и негативно отражаются на эффективности их функционирования на рынке и конкурентоспособности. Обоснована необходимость снижения логистических затрат на отечественных предприятиях. Предложены основные направления в сфере снижения логистических затрат на отечественных предприятиях.

Ключевые слова: отечественные предприятия, расходы, логистические затраты, управление логистическими затратами, снижение логистических затрат, логистический контроллинг.

Постановка проблеми у загальному вигляді і її зв'язок 3 важливими науковими та практичними завданнями. В даний час важливим аспектом зростання ефективності функціонування суб'єктів господарювання як на внутрішньому, так і на зовнішньому ринку, в умовах жорсткої конкуренції, $\epsilon$ пошук і застосування нових підходів до оптимізації витрат, пов'язаних 3 виробництвом і обігом продукції, що випускається.

Важливу роль у цьому може відіграти логістика та логістичні витрати, які представляють собою витрати, пов'язані з виконанням логістичних операцій і процесів (транспортування, складування, пакування тощо [1].

Аналіз останніх досліджень, у яких започатковано вирішення проблеми. Проблемі зниження логістичних витрат підприємств присвятили праці Балог Л.В., Безсмертна О.В., Крикавський В.Є., Радецька Л.П., Шварц І.В. тощо. Проте на вітчизняних підприємствах не приділяється належна увага управлінню логістичними витратами, що потребує ретельнішого вивчення даного питання.

Цілі статті. Ціль статті полягає у пошуку шляхів зниження логістичних витрат на вітчизняних підприємствах.

Виклад основного матеріалу дослідження 3 повним обгрунтуванням отриманих наукових результатів. Особливо актуальним с пошук шляхів зниження логістичних витрат 
Економічні науки: збірник наукових праць Луцького національного технічного університету. Серія "Регіональна економіка". Випуск 18 (71). Редкол.: відп. ред. д.е.н., професор Л.Л. Ковальська. Луиьк: ІВВ Луиького НТУ, 2021. 278 с.

для вітчизняних підприсмств. Адже на вітчизняних підприємствах не приділяється належна увага питанню управління логістичними витратами.

Витрати на логістику в Україні в даний час приблизно на 40 \% вищі, ніж в провідних країнах світу, і за таким показником, як індекс ефективності логістики, який розраховує Всесвітній банк, Україна істотно відстає від США і країн ЄС [2].

Згідно досліджень науковців логістичні витрати можуть сягати до $45 \%$ загальних витрат підприємства та становити до $16 \%$ його доходів (табл. 1).

Таблиця 1

Логістичні витрати підприємства

\begin{tabular}{|l|c|}
\hline \multicolumn{1}{|c|}{ Частка логістичних витрат } & Значення, \% \\
\hline У сукупних доходах підприємства & $7-16$ \\
\hline У адміністративних витратах підприємства & $10-35$ \\
\hline У загальних витратах підприємства & $20-45$ \\
\hline
\end{tabular}

Джерело: [3]

Ці високі значення логістичних витрат відображають їх суттєвий вплив на економічні показники діяльності підприємства та засвідчують потребу у пошуці шляхів їх зниження.

Для зменшення витрат підприємства потрібно володіти інформацією про тенденцію їх зміни та їх структуру. Упродовж 2015-2019 рр. на вітчизняних підприємствах спостерігалась тенденція до збільшення питомої частки витрат на оплату праці. В той же час питома частка матеріальних витрат, амортизації, відрахувань на соціальні заходи та інших витрат зменшилась.

Вивчення структури витрат вітчизняних підприємств свідчить, що найбільшу частку у їх виробничих витратах займають матеріальні витрати (71,4 \% у 2019 р.), другу за вагомістю позицію займають витрати на оплату праці (16,0 \% у 2019 р.), третю позицію - амортизація (7,3 \% у 2019 р.) (рис. 1, рис. 2) [4].

Таким чином, для пошуку шляхів зниження витрат вітчизняних підприємств в першу чергу слід звернути увагу на логістичні витрати пов'язані 3 управлінням матеріальними 
Економічні науки: збірник наукових праць Луцького національного технічного університету. Серія "Регіональна економіка". Випуск 18 (71). Редкол.: відп. ред. д.е.н., професор Л.Л. Ковальська. Луцьк: ІВВ Луцького НТУ, 2021. 278 с.

потоками на підприємстві. Слід приділяти увагу і питанням оптимізації витрат на оплату праці, оскільки протягом 2015-2019 pр. їх питома частка зросла на 3,9 відсоткові пункти.

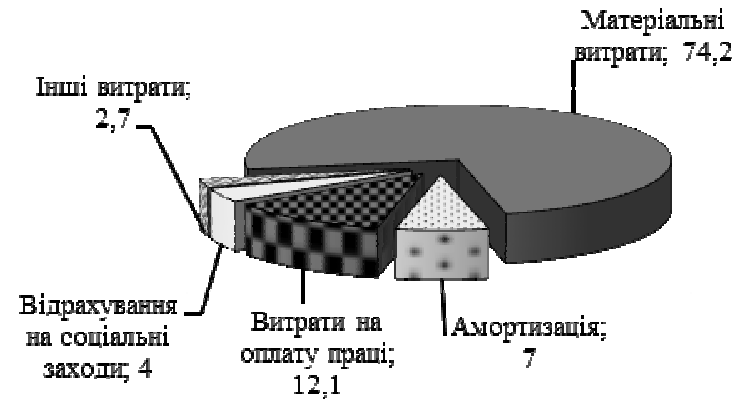

Рис. 1. Структура витрат підприємств в Україні на виробництво продукції (товарів, послуг) у 2015 р., \% Джерело: [4]

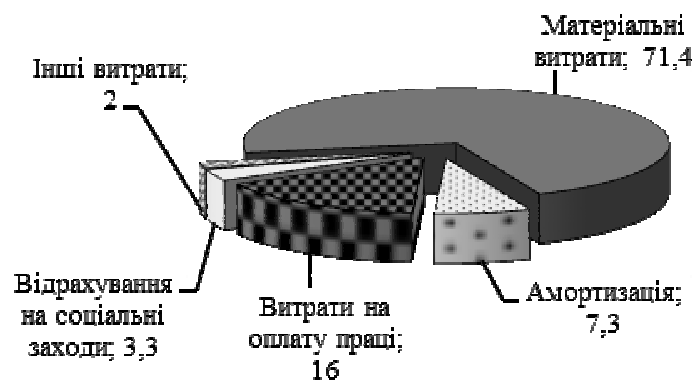

Рис. 2. Структура витрат підприємств в Україні на виробництво продукції (товарів, послуг) у 2019 р., \% Джерело: [4]

Структура логістичних витрат в розрізі функціональних сфер логістики представлена на рис. 3. 
Економічні науки: збірник наукових праць Луцького національного технічного університету. Серія "Регіональна економіка". Випуск 18 (71). Редкол.: відп. ред. д.е.н., професор Л.Л. Ковальська. Луцьк: ІВВ Луцького НТУ, 2021. 278 с.

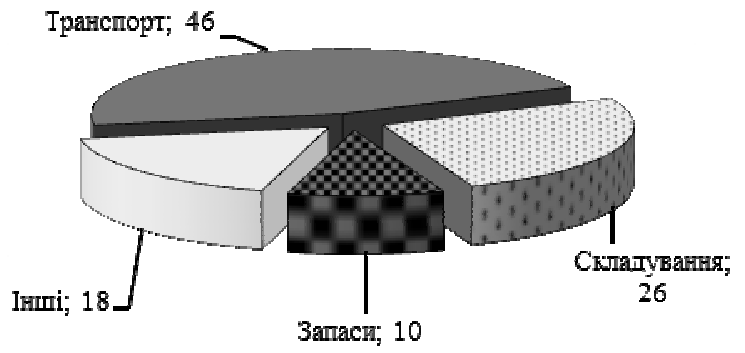

Рис. 3. Структура логістичних витрат в розрізі функціональних сфер логістики

Джерело: [3]

Дані рис. 3 свідчать, що на вітчизняних підприємствах найбільшу частку у логістичних витратах займають витрати на транспортування (46 \%) та складування (26\%). Отож, в процесі управління логістичними витратами підприємства, слід звертати увагу на пошук можливостей зниження саме цих видів логістичних витрат.

Для підвищення ефективності функціонування підприємства на ринку та його конкурентоспроможності слід докладати комплексні зусилля для зменшення різноманітних логістичних витрат. Можна виділити наступні підходи до зниження витрат у різних функціональних сферах логістики:

1. Логістика постачання: вибір постачальників ресурсів 3 найкращими пропозиціями цін і якості продукції; координація діяльності підприємства 3 постачальниками i можлива інтеграція; пошук дешевших замінників ресурсів; створення систем регулювання запасів; проведення інвентаризації; оновлення складського обладнання; зменшення ненормативних складських запасів; створення єдиної номенклатури для обліку та пошуку ресурсів на складах.

2. Логістика виробництва: інвестування в технологічне i технічне удосконалення виробництва (автоматизація, роботизація, комп'ютеризовані системи управління); вдосконалення організації виробництва i праці; аутсорсинг 
Економічні науки: збірник наукових праць Луцького національного технічного університету. Серія "Регіональна економіка". Випуск 18 (71). Редкол.: відп. ред. д.е.н., професор Л.Л. Ковальська. Луиьк: ІВВ Луиького НТУ, 2021. 278 с.

менш продуктивної діяльності; підвищення продуктивності праці і рівня механізації виробництва; підвищення технічного рівня виробництва; спрощення конструкції виробу.

3. Логістика розподілу: визначення точної структури ринку і прогноз попиту; точне дослідження каналів розподілу; підвищення точності дотримання термінів; координація діяльності підприємства 3 дистриб'юторами i можлива інтеграція; аутсорсинг другорядних процесів.

Важливим інструментом скорочення витрат на підприємстві є контролінг. Манн Р. та Є. Майнер трактують логістичний контролінг як систему забезпечення здатності підприємства до виживання [5].

Радецька Л.П. зазначає, що логістичний контролінг - це в першу чергу управління витратами, які є найважливішими для підприємства [6].

Об'єктом логістичного контролінгу виступають процеси виробництва як процеси збільшення його цінності і накопичення витрат, предметом - витрати і цінність продукту, що виробляється. Контролінг витрат полягає у виявленні факторів, що викликають відхилення фактичних значень витрат від планових, а також визначенні місця виникнення таких відхилень, знаходженні способів їх подолання та пошуку шляхів їх мінімізації.

Проведення логістичного контролінгу на підприємстві дозволяє [5]: оптимізувати логістичні витрати підприємства; збільшити прибуток підприємства; підвищити рентабельність функціонування підприємства.

Висновки. Таким чином, на вітчизняних підприємствах не приділяється належної уваги управлінню логістичними витратами, що призводить до зростання сукупних витрат та цін на їх продукцію. Це негативно відображається на ефективності функціонування вітчизняних підприємств на ринку та їх конкурентоспроможності і вимагає пошуку шляхів зниження логістичних витрат. Для зниження логістичних витрат на вітчизняних підприємствах слід підходити комплексно і шукати можливості їх оптимізації з врахуванням усіх сфер логістики. 
Економічні науки: збірник наукових праць Луцького національного технічного університету. Серія "Регіональна економіка". Випуск 18 (71). Редкол.: відп. ред. д.е.н., професор Л.Л. Ковальська. Луцьк: ІВВ Луцького НТУ, 2021. 278 с.

При цьому особливу увагу слід приділити запровадженню на вітчизняних підприємствах логістичного контролінгу.

\section{Список бібліографічного опису}

1. Крикавський В.Є. Логістика. Основи теорії : підруч. для вищ. навч. закл. Л. : Львівська політехніка, 2005. 683 с.

2. Эксперт: Логистика в Украине дороже, чем в ЕC и CША. URL: http://agroportal.ua/news/ukraina/ekspert-logistika-v-ukraine-dorozhe-chem-v-es-issha/ (дата звернення 02.10.2021).

3. Шварц І.В., Безсмертна О.В. Вплив структури логістичних витрат на фінансові результати молокопереробних підприємств. URL: http://globalnational.in.ua/issue-20-2017/28-vipusk-20-gruden-2017-r/3615-shvarts-i-v-

bezsmertna-o-v-vpliv-strukturi-logistichnikh-vitrat-na-finansovi-rezultatimolokopererobnikh-pidpriemstv

4. Державна служба статистики України. URL: http://www.ukrstat.gov.ua/ (дата звернення 05.10.2021).

5. Балог Л.В. Сутність логістичного контролінгу та його роль в процесі управління підприємством. URL: http://global-national.in.ua/archive/82015/64.pdf (дата звернення 05.10.2021).

6. Радецька Л.П. Удосконалення управління логістичними витратами у системі стратегічного управлінського обліку. Вісник Хмельницького національного університету. 2010. № 5. Т. 3. С. 243-246.

\section{References}

1. Krykavs'kyy V.Ye. (2005) Lohistyka. Osnovy teoriyi : pidruch. dlya vyshch. navch. zakl. L. : L'vivs'ka politekhnika [In Ukrainian].

2. Эkspert: Lohystyka v Ukrayne dorozhe, chem v ES y SShA. URL: http://agroportal.ua/news/ukraina/ekspert-logistika-v-ukraine-dorozhe-chem-v-es-issha/ [In Ukrainian].

3. Shvarts I.V., Bezsmertna O.V. Vplyv struktury lohistychnykh vytrat na finansovi rezul'taty molokopererobnykh pidpryyemstv. URL: http://globalnational.in.ua/issue-20-2017/28-vipusk-20-gruden-2017-r/3615-shvarts-i-v-

bezsmertna-o-v-vpliv-strukturi-logistichnikh-vitrat-na-finansovi-rezultatimolokopererobnikh-pidpriemstv [In Ukrainian].

4. Derzhavna sluzhba statystyky Ukrayiny. URL: http://www.ukrstat.gov.ua/ [In Ukrainian].

5. Baloh L.V. Cutnist' lohistychnoho kontrolinhu ta yoho rol' v protsesi upravlinnya pidpryyemstvom. URL: http://global-national.in.ua/archive/82015/64.pdf [In Ukrainian].

6. Radets'ka L.P. (2010) Udoskonalennya upravlinnya lohistychnymy vytratamy u systemi stratehichnoho upravlins'koho obliku. Visnyk Khmel'nyts'koho natsional'noho universytetu, no 5, t. 3, pp. 243-246 [In Ukrainian].

DOI: $\underline{\text { https://doi.org/10.36910/2707-6296-2021-18(71)-10 }}$ 